\title{
INDONESIA'S FDI - EXPORTS - GDP GROWTH NEXUS: TRADE OR INVESTMENT - DRIVEN?
}

\author{
Panky Tri Febiyansah ${ }^{1}$
}

\begin{abstract}
This paper examines the relationship between foreign direct investment inflow, export and economic growth in Indonesia in a dynamic framework. We uses vector error correction model to estimate the causal relationship between FDI, exports and GDP. The findings in Indonesia's case verify the proposition that FDI plays an important role which, in turn, together with joint FDI-exports can promote economic growth in the immediate short run and improve the competitiveness for Indonesia's commodity exports. Nonetheless, the absence and existence of economic growth effects to FDI and exports respectively indicate that Indonesia still has several domestic economic constraints. It denotes that Indonesia's economic structure is still transforming and far from adequate. Indonesia needs bold policies in order to accelerate its economic growth and further integrate trade chains for reducing domestic economic restrictions and improving Indonesia's degree of competitiveness.
\end{abstract}

Keywords: Export, Foreign Direct Investment, Growth.

JEL Classification: C32, F14, F21, F41

1 Panky Tri Febiyansah, MIDEC is the reseacher in Research Centre for Economics (P2E) - The Indonesian Institute of Sciences (LIPI). Email: (panky_ie@yahoo.com). 


\section{INTRODUCTION}

The global economic condition is usually considered to be one of the most important determinants of developing-small open economy (DSOE) countries (Worldbank 2014). This relationship has grown increasingly significant in recent years because world trade and capital movement are more integrated. As a consequence, the world economic activities generate higher world income growth. A recent trend is that there is a huge capital movement inflowing to DSOE countries, especially foreign direct investment (FDI), which can improve economic growth domestically (Gossel \& Biekpe 2013). The role of FDI in influencing domestic growth occurs by creating an increase in product competitiveness, technological transfer and facilitating access to world market (Andraz \& Rodrigues 2010).

However, empirical evidence shows different experiences in different developing countries that have resulted in highlighting different directional relationships between a country's openness and GDP growth. The variation of a country's openness to investment and trade has implications for the country's economic growth.

Some findings show that FDI has a significant effect in developing countries. There are two ways in which this occurs. In general cases, the channel of FDI in influencing the economy is by stimulating productivity growth and exports. This is called the FDI-led export growth hypothesis (FLEH). Principally, FDI comes from multinational companies that create better productivity, technological transfer, managerial skill and higher capacity of production in the host country leading to enhancing its capacity to export (Temiz \& Gokmen 2011).

A clear evidence-based example about the role of FDI is the case of China which was conducted by Gharana and Adhikari (2011). Also, the increasing in capacity of host country can attract FDI due to its growing market size, the improvement in infrastructure and growing human resources which can be called the growth-led FDI hypothesis (GLFH). This hypothesis can be seen in India as the distinct example.

There is evidence that exports are a significant determinant of a country's output growth. Exports will deliver an incentive to producers for supplying foreign demand for goods and services. This incentive leads to wide production capacity, higher endowment utilization and decreased unemployment (Balassa 1978). It is called export-promoted hypothesis. It is based on the principle that by generating a spillover effect can drive economic growth (Shabaz et. al. 2011)

Alternatively, economic growth can enhance technological progress, capital capacity and human productivity. It leads to a more attractive endowment factor which, in turn, will generate the ability of firms to gradually increase their production and export their products. However, other studies show that the relationship between exports and growth is bi-directional (Andraz \& Rodrigues 2010 and Doyle 2001). These indications imply that either export-led economic growth (ELGH) or economic growth-led exports hypothesis (GLEH) can generate a country's 
economic performance. How effectively then the above characteristics are interacting in a country is a matter for empirical study and can be examined by testing the FDI-exports-GDP growth nexus in the country.

Since the Asian financial crisis (AFC) in 1997/98, Indonesia has been recovering rapidly that can be seen by higher economic growth, export growth and inward FDI growth. This performance was certainly remarkable from 2004 to 2006. Unfortunately, the global financial crisis (GFC) in 2008 affected almost all countries in the world including Indonesia. However, Indonesia's economic performance was relatively stable in terms of the ability to absorb external shock. Hence, this paper aims to examine the relationship between foreign direct investment inflow, export and economic growth in Indonesia.

According to several theoretical and empirical views, obtaining a better insight for the real determinants of economic growth in Indonesia is straightforwardly required by assessing the FDI-export-GDP link as a fundamental basis. Up to this point, examining the FDI-export-GDP nexus has not yet been made in the suitable learning of Indonesia's experience. Drawing on Toda and Phillips (1993) and Andraz and Rodrigues (2010), this paper uses current advanced modelling for time series framework by using vector error correction model, through the maximum likelihood estimator that comes from Johansen (1988) method, to identify and estimate the above causal relationship between FDI, exports and GDP.

Empirical outcomes denote the presence of a long run relationship in the FDI-exportsGDP growth nexus, in turn, there is bi-directional causality in the FDI-exports relation and single-causal direction moving from FDI and GDP to GDP and exports respectively. This paper is arranged as follows. Section 2 presents a brief review of literature. Section 3 discuses analytical framework, and model used. Section 4 describes the set of data that used in the estimation. At last, concluding remarks and policy implications are provided in section 5 .

\section{THEORY}

The literature review will provide the applied findings to build a framework. However, there is no previous study which has a similar aim of this paper using Indonesia time series data. In order to solve this issue, empirical results from the experience of other countries will be applied. Moreover, large empirical studies which related to this study have been undertaken, whether the estimation of FDI and exports over economic growth was employed either separately or continuously.

To some extent, comparing the findings in terms of direction of causality and magnitude of effect are relatively complicated. The complexity comes from the difference in the stage of economy development, the characteristic of economic building and additional variables included in the FDI-export-GDP model, such as: human capital, exchange rate, imports, legal binding, infrastructure and domestic investment. These imply that the compared procedures will be slightly challenging and the estimated outcome is inevitably different. 
The literature, which talking about the relationship between investment inflow, export and economic growth on this paper's focus, is extensive. For example, Giles and Williamson (2000a, b), Tarzi (2005), Kondeker and Kalirajan (2010) and Kinda (2010) describe comprehensively the interaction between FDI and economic growth in the host country. On the other hand, Balassa (1978) and Sannassee et al. (2014) work for the underlying study about how the exports and economic activities can be closely related.

Another research is also convincing in order to explain the exports-GDP nexus was conducted by Felipe (2003) and provides comprehensive perspective about the importance and constraints of the exports-led growth paradigm in developing Asian countries post Asian financial crisis 1997s. Relating to above reviews, the focus on this paper can only be separately illustrated and cannot emphasise interactively the effects of both FDI and exports. As a result, this study needs to provide several criteria to shape this review of literature in order to assess the impacts of FDI, exports and both FDI and exports on economic growth.

First criteria are to provide studies which simply test the influence of FDI on economic growth with no exports. Zhang (2001), Li and Liu (2005) and Oladipo (2013) point out that there was significant linkage between FDI and economic growth in DSOE countries. Chakraborty \& Basu (2002) supports GDP-led FDI hypothesis for India, while Nabende et al. (2003) demonstrate that FDI has encouraged economic growth in selected East Asian countries through both direct effect and indirect effect as a result of spillover process. However, Attari et al. (2011) find in Pakistan case that there was no causality between FDI and GDP, although there was the long-run relationship when trade variables were included in the model. Furthermore, Qi (2007) presents diverse results on the relationship between FDI and GDP in 47 countries which suggest that FDI performance was more convincing in developed countries than in developing countries.

A second criteria of studies categorises exports as the only determinant of economic growth with no FDI. Parida and Sahoo (2007) found the relationship in long-run equilibrium in four South Asian countries between exports and growth was significantly correlated which supported ELGH. Similarly, Doyle (2001) found that both ELGH and GLEH have been identified in Irish that clearly illustrated a virtuous circle of exports and GDP. Though, Tang and Ravin (2013) also describe the exports-driven growth hypothesis in Cambodia has existed.

On the other hand, Gagnon (2008) points out that the long run trend of GLEH in 96 countries was considerable coming from stable terms of trade. Regarding those studies, the dominant effect between ELGH and GLEH is varied, which is similar to Bahmanian and Economidou's (2009) finding that there is no identical pattern either in the long run relationship or short run effect suggesting that the nexus depends on country-specific attribute.

Finally, several studies exhibit evidence on the link between FDI, exports and economic growth. Andraz and Rodrigues (2010) demonstrate that FDI, exports and growth had a long run relationship, while FLGH and GLFH prevailed on short run causal-directional by using vector error correction model and causality test to estimate Portugal data. Making similar finding 
on Thailand time series data, Kohpaiboon (2003) presented FDI as a main driver in boosting economic openness and growth using Engle-Granger causality test. Furthermore, there is a different story from China: Gharana and Adhikari (2011) used augmented vector autoregression (A-VAR) model and found convincing outcomes that FDI and exports drove China's growth in the post-liberalisation era.

\section{METHODOLOGY}

\subsection{Estimated Model}

This paper applies a standardized procedure of unit-root test, co-integration test, and causality tests. The aim of the procedure is to present empirical calculation of the relationship between FDI, export and economic growth.

Granger proposes the 'Granger test' to examine the causality that is suitable tool for the process of integrated series. However, Granger and Newbold (1974) also describe that time series data tend to be random-walks and it can cause miss-specification equations when estimating causality test. Moreover, if the co-integrated data cannot hold, granger test will be inacceptable and the results are ambiguous (Granger, 1988). As a result, Granger (2010) suggesting error correction model can be used to test causality when the data series are not co-integrated. Thus, there is a proper procedure in examining causality that also including stationary and co-integration tests.

Unit-root test is procedure to examine stationarity of the time series whether the data have a unit-root or that the series data is a random-walk process (Dickey \& Fuller 1979). This test is beneficial to avoid a spurious regression. Stationarity test in this study follows modified test of standard dickey-fuller procedure by Elliott et al. (1996) named dickey fuller with generalized least squares (DF-GLS) which is more powerful and works satisfactorily in a small data series. The DF-GLS test is constructed as below:

$$
\Delta z_{t}^{\circ}=\alpha+\beta z_{t-1}^{\circ}+\sum_{m=1}^{n} \theta_{m} \Delta z_{t-m}^{\circ}+\epsilon_{t}
$$

where $\Delta=-(L-1)$ is built by standard lag operator. $\varepsilon_{t}$ is a white-noise signal, while $z^{\circ}$ characterise the locally de-trended time series. The difference between dickey fuller (ADF) and DF-GLS is to estimate GLS prior to test ADF. Moreover, the null hypothesis is $\beta=0$, which shows that the series variable has a unit root, while the estimated unit root is binding with the lag length of model that provided selection information criteria ( $\mathrm{Ng} \&$ Perron 2001). It implies that DF-GLS will provide suitable stationarity test with lag selection. 
After estimating unit-root test, if the two series are $C_{t} \sim 1(1)$ and $D_{t} \sim 1(1)$, degree one integration, and the estimation of $E_{t}=C_{t}-\psi D_{t}$ results in $E_{t} \sim 1(0)$, the co-integration of the two series exists (Engle \& Granger 1987). In this instance, the linear combination of these series can be represented as at least one-way relationship in the long-run equilibrium. In addition, Granger performs the co-integrated I(1) data series in the procedure of vector autoregression (VAR) model. By using $n$ lags, a VAR equation is built as follows:

$$
\mathrm{Z}_{\mathrm{t}}=\mathrm{u}+\mathrm{A}_{1} \mathrm{Z}_{\mathrm{t}-1}+\mathrm{A}_{2} \mathrm{Z}_{\mathrm{t}-2}+\mathrm{A}_{3} \mathrm{Z}_{\mathrm{t}-3}+\cdots+\mathrm{A}_{\mathrm{n}} \mathrm{Z}_{\mathrm{t}-\mathrm{n}}+\epsilon_{\mathrm{t}}
$$

where $Z_{t}$ is a $k \times 1$ vector of variables, $u$ is a $k \times 1$ vector of intercept's parameters, $A 1-A n$ are $k \times k$ matrices of equation's parameters, and $\varepsilon_{t}$ is a $k \times 1$ vector of shocks. $\varepsilon_{t}$ should have mean around 0 , have covariance matrix $\Sigma$;, and be normal upon a time in terms of independent and identically distributed. For the aims of this study by using $Z_{t}=\left[G D P_{t^{\prime}}, F_{t^{\prime}}, E X_{t}\right], V A R$ model with $\mathrm{n}$ lags need to be converted into vector error correction model (VECM). The form of VECM can be stated as below:

$$
\Delta Z_{t}=y+\pi Z_{t-1}+\sum_{m=1}^{n-1} \tau_{m} \Delta Z_{t-m}+\epsilon_{t}
$$

where

$$
\pi=\sum_{m=1}^{n} A_{m}-I_{n}
$$

and

$$
\tau_{m}=-\sum_{m+1}^{n} A_{m}
$$

Based on the assumption that $Z_{t}$ must be linear combination of variables in $1(1)$, these first-order integrated variables prevail. Afterwards, the rank of matrix $\pi$ reduces and can be rearranged becoming $\alpha \beta^{\prime}$. The decomposition of (3) using $\alpha \beta^{\prime}$ can be presented as:

$$
\Delta Z_{t}=y+\alpha \beta^{\prime} Z_{t-1}+\sum_{m=1}^{n-1} \tau_{m} \Delta Z_{t-m}+\epsilon_{t}
$$

Moreover, $\pi$ is called as identified effect matrix which $\alpha$ and $\beta$ are the vector of correction coefficients and the cointegrating links respectively. 
According to previous explanation about the importance of cointegrating relationships, this study need to first look for long run relations for generated variables within each model. In order to estimate cointegration relationship on VAR process, Johansen (1988) procedure is satisfied to support VECM by deriving maximum likelihood and generating independent identically distributed Gaussian errors.

Note which $r$ representing cointegration rank, satisfying $\alpha \beta^{\prime}$ needs $r$ greater than zero and less than $k$ as a restriction to avoid non-singular matrix. It implies VECM can be used to distinguish appropriate cointegrating area. In practice, before finding cointegration system, optimal restricted can be beneficial to find optimal lag length which can perform suitable cointegration rank. Technically, restricted $r$ is placed as null hypothesis which is examined by likelihood statistics through trace test (Johansen 1991).

Extending equation (6) in terms of employed variables, the form of GDP-FDI-exports is demonstrated as below:

$$
\begin{aligned}
{\left[\begin{array}{c}
\Delta G D P_{t} \\
\Delta F D I_{t} \\
\Delta E X_{t}
\end{array}\right]=\left[\begin{array}{ccc}
\alpha_{1} & 0 & 0 \\
0 & \alpha_{2} & 0 \\
0 & 0 & \alpha_{3}
\end{array}\right]\left[\begin{array}{l}
\mu_{1, t-1} \\
\mu_{2, t-1} \\
\mu_{3, t-1}
\end{array}\right] } \\
+\left[\begin{array}{llll}
\sum_{m=1}^{n} \vartheta_{11} L^{m} & \sum_{m=1}^{n} \vartheta_{12} L^{m} & \sum_{m=1}^{n} \vartheta_{13} L^{m} \\
\sum_{m=1}^{n} \vartheta_{21} L^{m} & \sum_{m=1}^{n} \vartheta_{22} L^{m} & \sum_{m=1}^{n} \vartheta_{23} L^{m} \\
\sum_{m=1}^{n} \vartheta_{31} L^{m} & \sum_{m=1}^{n} \vartheta_{32} L^{m} & \sum_{m=1}^{n} \vartheta_{33} L^{m}
\end{array}\right]\left[\begin{array}{c}
\Delta G D P_{t} \\
\Delta F D I_{t} \\
\Delta E X_{t}
\end{array}\right]+\left[\begin{array}{l}
\epsilon_{1 t} \\
\epsilon_{2 t} \\
\epsilon_{3 t}
\end{array}\right]
\end{aligned}
$$

Where $\Delta$ represents first difference process, $\mathrm{n}$ is the order of lags and $\varepsilon_{\mathrm{i}, \mathrm{t}}$ is a non-serially correlated error periods. Furthermore, the parameters of $\vartheta_{\mathrm{kj}, \mathrm{i}}$ show the dynamics in short-run terms. By the assumption, $\mu_{\mathrm{i}, \mathrm{t}-\mathrm{1}}$ has to be under stationary level which performs the $\mathrm{I}(1)$ lagged significance of the errors from the cointegration equations as follows:

$$
\left[\begin{array}{c}
G D P_{t} \\
F D I_{t} \\
E X_{t}
\end{array}\right]=\left[\begin{array}{l}
\delta_{1} \\
\delta_{2} \\
\delta_{3}
\end{array}\right]+\left[\begin{array}{ccc}
0 & \tau_{12} & \tau_{13} \\
\tau_{21} & 0 & \tau_{23} \\
\tau_{31} & \tau_{32} & 0
\end{array}\right]\left[\begin{array}{c}
G D P_{t} \\
F D I_{t} \\
E X_{t}
\end{array}\right]+\left[\begin{array}{c}
\mu_{1 t} \\
\mu_{2 t} \\
\mu_{3 t}
\end{array}\right]
$$

The determinants of $\tau_{\mathrm{ij}}$ are the coefficients of long run equilibrium. In order to confirm causal relationship, this study based on equation (7) needs an additional verification that is performed by both t-test and joint significance test to first order lagged GDP $\mathrm{t}^{\prime} \mathrm{FDI}_{\mathrm{t}}$ and $\mathrm{EX}_{\mathrm{t}}$. It 
infers to Granger test in generating causality. However, since granger causality method is really responsive to the lag creteria, the schwartz information criterion (SIC) is essential to handle in order to determine proper lags on the model.

\subsection{Data}

The set of data consists of quarterly observations of real gross domestic product (GDP), real inflow foreign direct investment (FDI), and real exports (EX) in Indonesia from 2000:01 to 2012:04. This aims to isolate the effect of structural change in the Indonesia economy which was converting from fixed exchange rate to floating exchange rate regime caused by AFC. The data set was obtained from the Indonesia's central bank (BI) and bureau statistics databases (BPS) and international financial statistics (IFS-IMF).

The preference of FDI inflow than FDI outflow comes from the framework of DSOE countries which inward FDI plays a more significant role in the Indonesia economy. Furthermore, FDI inflow in total in time $t$ is first-difference significance as a channel to deliver advanced technical transfer and as an incentive to generate innovation.

Specifically, FDI is the flow variable. In order to observe production capacity in the growth process, production function context can be adopted to frame. It implies that FDI should be converted into capital stock to explain the existence of lifetime impacts on Indonesia economy. Coming along with exports, it can measure the expanding level of Indonesia development. Instead stock capital is available on UNCTAD, this study still prefers developing the data by estimating equation (9) due to the absence of quarterly data. Clearly, variable FDI is used to generate capital stock data by following difference equation:

$$
K_{t+1}=K_{t}-\delta K_{t}+F D I_{t+1}
$$

Where $\mathrm{K}_{\mathrm{t}+1}$ is the capital stock in next period, $\mathrm{K}_{\mathrm{t}}$ is capital stock in current period, $\delta$ presents annual depreciation rate, that is constant about 5 per cent, and FDI tr+ $_{\text {in }}$ inward FDI in next period. According to the definition, equation (9) requires initial capital stock. Noting 1999:04 as the initial period $\left(\mathrm{K}_{1999: 04}\right)$, this equation can be assumed that $\mathrm{K}_{2000: 01}=\mathrm{FDI}_{2000: 01}$, which is, $\mathrm{FDI}$ is equal to Capital stock in the first period assuming $\mathrm{K}_{1999: 04}$ is $\mathrm{K}$ in period zero. Since the depreciation is annual, this rate needs to be converted into quarterly series.

Figure 1 exposes distinct evidence that GDP, FDI and exports move in upward trends and tend to mutually progress each other. This pattern exhibits convergence development of Indonesia economy along time path. However, the move of FDI and exports is interesting to explore. Indonesia FDI looks like better because, since 2006 quarter 1, the move of FDI have preceded exports trend. 
The cross trend is important to understand that caused by not only significantly increasing FDI but also flatter exports performance in the time periods. It implies Indonesia's exports does not have steady phase in terms of maintaining export growth.

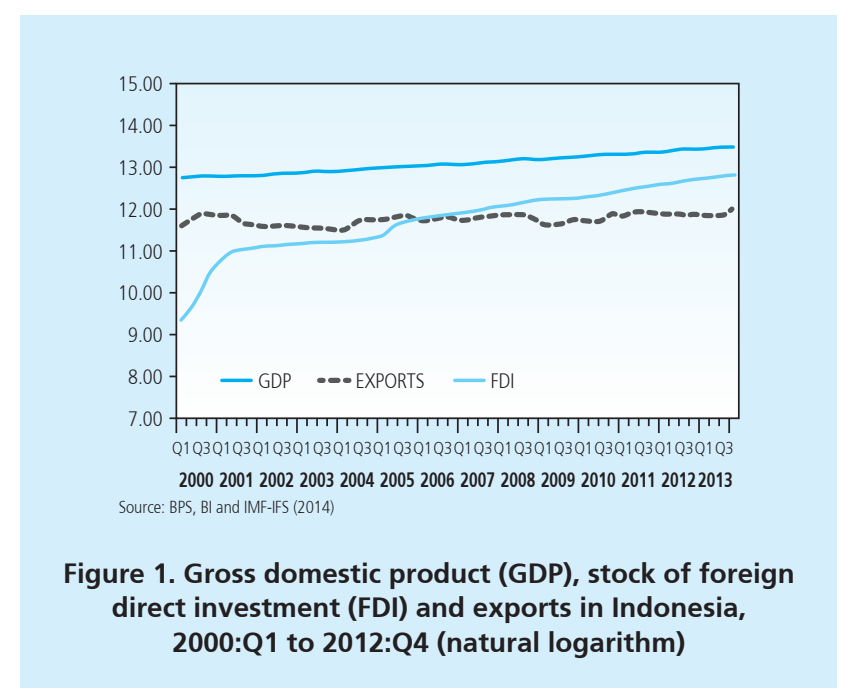

Figure 2 presents the growth rates of GDP, exports and FDI in year-on-year (YoY) approach to likewise capture seasonality effects in one year. The average quarterly YoY growth of GDP was relatively stable around 5.45 per cent over the periods. In particular considering to the effect of GFC in 2008, the data can be separated into 2000-2007, 2008-2009 and 2010-2013 which the average growth rates were 5.07 per cent, 5.32 per cent and 6.19 per cent, respectively.

Meanwhile, the FDI as a stock capital performed relatively impressive prior to GFC's shock compared to preceding periods. The average growth of FDI was around 46 per cent within 2000-2007, while lower growths were 15 per cent and 14.22 per cent in the periods of 20082009 and 2010-2013. Instead it had decreasing trend of FDI growth, but it was still high and realistic to boost economic growth. Overall, this condition still leads to convincing expansionary stage of Indonesia's economic performance. 


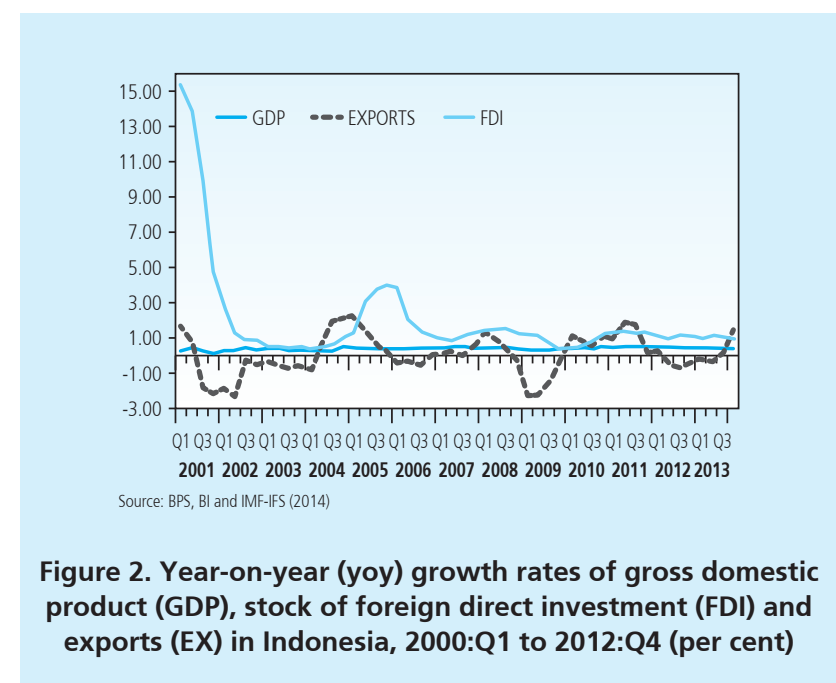

From the pattern of exports, it had less productive performance in preventing growth phase of Indonesia. This condition may come from the increasing costs per unit worker, world price and demand of exported commodities then primary-based export compositions.

One important thing to underline is in developing country, Indonesia's case, exports performance tends to have no time trend. It is realistic because Indonesia exported goods highly depend on world price and demand which drive exports to move volatile.

Placing the time prior to and preceding GFC period, Figure 2 presented exports were 0.73 per cent, -4.55 per cent and 6.64 per cent, respectively. The growth rate about 6.64 per cent was interestingly caused by increasing demand of its exported commodities which is from Asian countries for example China as one of Indonesia's partner.

\section{RESULTS AND ANALYSIS}

This study conducts the formal test to confirm the variables are stationary. Table 1 presents estimated result of unit root test. The outcomes propose that all log form of series are stationary on the first difference and have non-stationary condition on level. This indication can also be seen visually on figure 1 which sketched moving-upward trends. These outcomes confirm that GDPt, FDIt and Ext are considered having order one integration I(1) and possibly lead to cointegrating relation. 


\begin{tabular}{l|c|c} 
& \multicolumn{1}{c}{$\begin{array}{c}\text { Table 1. } \\
\text { Unit-root tests }\end{array}$} \\
\hline Variable & Level & First difference \\
\hline GDP & -0.776 & $-3.687^{* *}$ \\
\hline FDI & -1.089 & $-4.463^{*}$ \\
\hline EX & -1.862 & $-3.722^{*}$ \\
\hline $\begin{array}{l}\text { Note: P-value shows the significance level by }{ }^{*}=1 \% ;{ }^{* *}=5 \% ;{ }^{* * *}=10 \% \\
\text { Source: Stata result }\end{array}$
\end{tabular}

The next step of the procedure is to verify the variables are either cointegrated or not. In order to undertake this step, we follow the Johansen and Julius cointegration assessment (JJcointegration test). However, prior to execute JJ-cointegration test, there is a test which should provide the optimal lag selection from five information criteria, such as: Likelihood Ratio, Final Prediction Error, Akaike Information Criterion, Hannan and Quinn Information Criterion and Schwarz Bayesian Information Criterion. The result of lag length selection is presented on table 2 which proposes VEC model to use lag 4.

\begin{tabular}{|c|c|c|c|c|c|}
\hline \multicolumn{6}{|c|}{$\begin{array}{l}\text { Table } 2 \text {. } \\
\text { The selection of lag length criteria }\end{array}$} \\
\hline Lag & 0 & 1 & 2 & 3 & 4 \\
\hline LR & & 391.74 & 34.602 & 24.873 & $128.43^{\circ}$ \\
\hline FPE & $4.20 \mathrm{E}-06$ & 3.10E-09 & 2.30E-09 & 2.00E-09 & $2.5 \mathrm{E}-10^{\circ}$ \\
\hline $\mathrm{AIC}$ & -3.87659 & -11.0639 & -11.3832 & -11.5153 & $-13.6389^{\circ}$ \\
\hline HQIC & -3.83343 & -10.8913 & -11.0811 & -11.0838 & $-13.0779^{\circ}$ \\
\hline SBIC & -3.76401 & -10.6136 & -10.5952 & -10.3896 & $-12.1755^{\circ}$ \\
\hline \multicolumn{6}{|c|}{$\begin{array}{l}\text { Note: } \mathrm{LR}, \mathrm{FPE}, \mathrm{AIC}, \mathrm{HQIC} \text { and } \mathrm{SBIC} \text { stand for like lihood ratio, final prediction error, akaike information, hanan-quinn information and schwartz } \\
\text { bayesian information creterion, respectively that are shown by }{ }^{\circ} \text { as lag selected } \\
\text { Source: Stata result }\end{array}$} \\
\hline
\end{tabular}

To some extent, a distinctive attribute of error correction form in equation (3) contains variables in first-difference and level orders. It results in a deviation of asymptotic distribution of test-statistic to the deterministic elements over cointegrating test. In resolving this constraint, table 3 shows trace statistic which developed by Johansen (1995). Trace statistic generates a joint test to reveal cointegrating rank which showing this model is appropriate for the deterministic elements. The principal use is to look for maximum rank by pointing to trace statistic. 


\begin{tabular}{|c|c|c|c|}
\hline \multicolumn{4}{|c|}{$\begin{array}{c}\text { Table } 3 . \\
\text { Cointegration test - Johansen approach }\end{array}$} \\
\hline Maximum rank & Eigenvalue & Trace Statistic & 5 percent critical value \\
\hline 0 & - & 45.8639 & 29.68 \\
\hline 1 & 0.44718 & $15.0419^{* *}$ & 15.41 \\
\hline 2 & 0.2168 & 2.335 & 3.76 \\
\hline 3 & 0.04391 & & \\
\hline \multicolumn{4}{|c|}{$\begin{array}{l}\text { Note: ** indicates } 5 \text { per cent of significance level } \\
\text { Source: Stata result }\end{array}$} \\
\hline
\end{tabular}

The results of cointegration - Johansen test are presented in table 3 which maximum eigenvalue and trace statistic recommends rank 1 by rejecting null hypothesis at 5 per cent of significance level. It means that the model has one cointegrating vector. As a result, cointegration test confirms that there are long run nexus between GDPt, FDIt and Ext inferring the tendency to all of variables to move simultaneously.

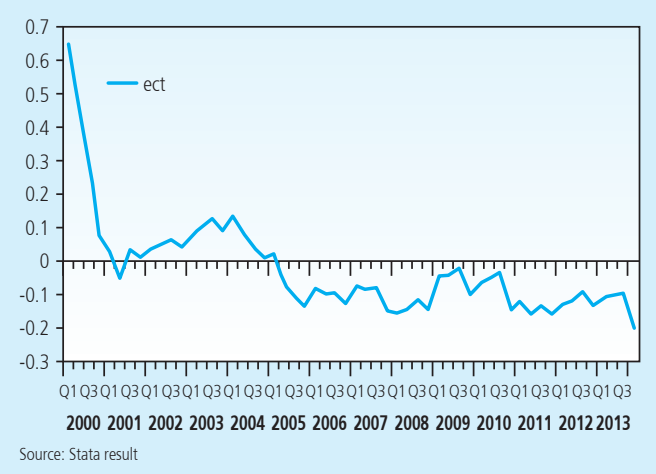

Figure 3.

The relationship on cointegration estimation

To some extent, Figure 3 also supports that the model is cointegrated in the long run with respect to GDP at time series. The residual behaviour of cointegrating calculation (ect) is stationary over the time periods that verifies the model is at one cointegrated vector.

According to cointegration test, the equation corresponding to the presence of long run relationship can be seen as below:

$$
\begin{aligned}
& \widehat{G D P}_{t}=6.8521+0.2427 F D I_{t}+0.2874 E X_{t} \\
& (t-\text { statistic })
\end{aligned}
$$


Equation 10 exhibits the crowding-in result of FDI and exports over Indonesia's output in the long run. In particular, since all variables are in logarithm forms, the predicted coefficients of explanatory variables are translated into elasticity's values. The critical significant level at 1 per cent shows that the raise of 1 per cent in FDI and exports will increase GDP around 0.24 per cent and 0.29 per cent, respectively, within ceteris paribus condition. In other words, this equation reveals that external factors expressed by FDI and exports have created valuable effects on the growth of GDP.

\begin{tabular}{|c|c|c|c|c|c|c|c|c|c|c|c|c|c|c|}
\hline & & & & & & Multi & ivariate & $\begin{array}{r}\text { Table } \\
\text { e error-c }\end{array}$ & $\begin{array}{l}4 . \\
\text { orrection n }\end{array}$ & model & & & & \\
\hline \multirow[t]{4}{*}{ DGDPt } & $=-0.05^{*}$ & \multirow[t]{2}{*}{$(-0.4$} & \multirow[t]{2}{*}{$\mathrm{FDI}^{\mathrm{t}-1}$} & \multirow[t]{2}{*}{ - } & \multirow[t]{2}{*}{0.44} & \multirow[t]{2}{*}{$E X^{t-1}$} & \multirow[t]{2}{*}{ - } & \multirow[t]{2}{*}{ 3.27) } & \multirow{2}{*}{$\begin{array}{r}-0.89^{*} \\
(-16.46)\end{array}$} & \multirow[t]{2}{*}{$\mathrm{DGDP}^{\mathrm{t}-1}$} & $-1.03^{*}$ & $D_{G D P}{ }^{t-2}$ & $-\quad 0.95^{\star}$ & \multirow[t]{2}{*}{ DGDP } \\
\hline & $(-4.6)$ & & & & & & & & & & $(-17.19$ & & $(-16.40)$ & \\
\hline & -0.01 & DFDI $\left.\right|^{-1}$ & + & 0.02 & $\left.D F D\right|^{-2}$ & - & $0.04^{*}$ & $\mathrm{DFDI}^{-3}$ & $+0.05^{*}$ & $D E X^{t-1}$ & $+0.03^{*}$ & $D E X^{1-2}$ & $+0.03^{*}$ & $D E X^{1-3}$ \\
\hline & $(-0.64)$ & & & $(0.71)$ & & & $(-2.50)$ & & $(3.56)$ & & (2.03) & & $(2.29)$ & \\
\hline \multirow[t]{4}{*}{ DFDI ${ }^{t}$} & $=0.04$ & $(-0.4$ & $\mathrm{FDI}^{\mathrm{t}-1}$ & - & 0.44 & $E X^{t-1}$ & - & $3.27)$ & $+\quad 0.15$ & DGDP $\mathrm{t}^{\mathrm{t}-1}$ & +0.004 & DGDPt-2 & $+\quad 0.23$ & $\mathrm{DGDP}^{\mathrm{t}-3}$ \\
\hline & $(0.78)$ & & & & & & & & $(0.55)$ & & $(0.01)$ & & $(0.82)$ & \\
\hline & $+0.3^{*}$ & DFDI & + & $0.19^{*}$ & $\mathrm{DFDI}^{-2}$ & - & 0.1 & $\mathrm{DFDI}^{\mathrm{t}}$ & +0.08 & DEX ${ }^{t-1}$ & 0.01 & $\mathrm{DEX} \mathrm{X}^{\mathrm{t}-2}$ & $+0.16^{*}$ & $D E X^{t-3}$ \\
\hline & $(2.98)$ & & & $(1.76)$ & & & $(-1.21)$ & & $(1.06)$ & & $(0.19)$ & & (2.38) & \\
\hline \multirow[t]{4}{*}{ DEX } & $=0.04$ & $(-0.4$ & $\mathrm{FDI}^{\mathrm{t}-1}$ & - & 0.44 & $E X^{t-1}$ & - & $3.27)$ & $+1.22^{*}$ & DGDPt-1 & 0.51 & DGDPt-2 & - $\quad 0.14$ & DGDPt-3 \\
\hline & $(0.78)$ & & & & & & & & $(2.13)$ & & $(-0.81)$ & & $(-0.23)$ & \\
\hline & +0.34 & DFDI $\left.\right|^{-1}$ & + & 0.23 & DFDIt-2 & - & $0.45^{*}$ & $\mathrm{DFDI}^{\mid-3}$ & - $\quad 0.04$ & $D E X^{t-1}$ & 0.04 & DEX ${ }^{1-2}$ & 0.09 & $D E X^{1-3}$ \\
\hline & $(0.16)$ & & & $(0.99)$ & & & $(-2.60)$ & & $(-0.29)$ & & $(-0.27)$ & & $(-0.64)$ & \\
\hline
\end{tabular}

The estimated outcomes of the multivariate error-correction model that are presented in table 4. At the same time, table 5 also shows that FDI-export-GDP nexus model has no autocorrelation and the residual is normally distributed. Moreover, figure 4 presents all eigenvalues place on the circle which means the model is not misspecified.

\begin{tabular}{|c|c|c|c|}
\hline \multicolumn{4}{|c|}{$\begin{array}{l}\text { Table } 5 \text {. } \\
\text { the analysis for residual behaviour }\end{array}$} \\
\hline & \multicolumn{2}{|c|}{ Diagnostic on Autocorrelation } & \multirow{2}{*}{$\begin{array}{c}\text { Diagnostic on Normality } \\
\text { Jarque-Bera }\end{array}$} \\
\hline & Lagrange-Multiplier (lag-1) & Lagrange-Multiplier (lag-4) & \\
\hline Statistics & 14.34 & 7.47 & 3.46 \\
\hline$P$ - values & 0.11 & 0.59 & 0.18 \\
\hline \multicolumn{4}{|c|}{$\begin{array}{l}\text { Note: Null hypothesis for Lagrange-Multiplier: no autocorrelation at lag order } \\
\text { Null hypothesis for Normality: residual is normally distributed } \\
\text { Source: Stata result }\end{array}$} \\
\hline
\end{tabular}


These imply that all fundamental assumptions of the FDI-export-GDP nexus model hold. Consequently, the coefficient of error-correction term around - 0.05 on DGDPt denotes the ability of adjustment's speed is relatively slow in order to drive converging to equilibrium condition at the 1 per cent critical level. This can be illustrated as follows. If a disturbance creates the variation on GDP level during recent period, the deviation will be adjusted by 5 per cent to move back into equilibrium level in the following period. However, the adjustment values of both DFDIt and DEXt are not statistically significant on the critical level and have positive signs. This condition may arise in error-correction modelling because the adjustment multiplier effects are frequently counterbalanced by the dynamics of short-run circumstance.

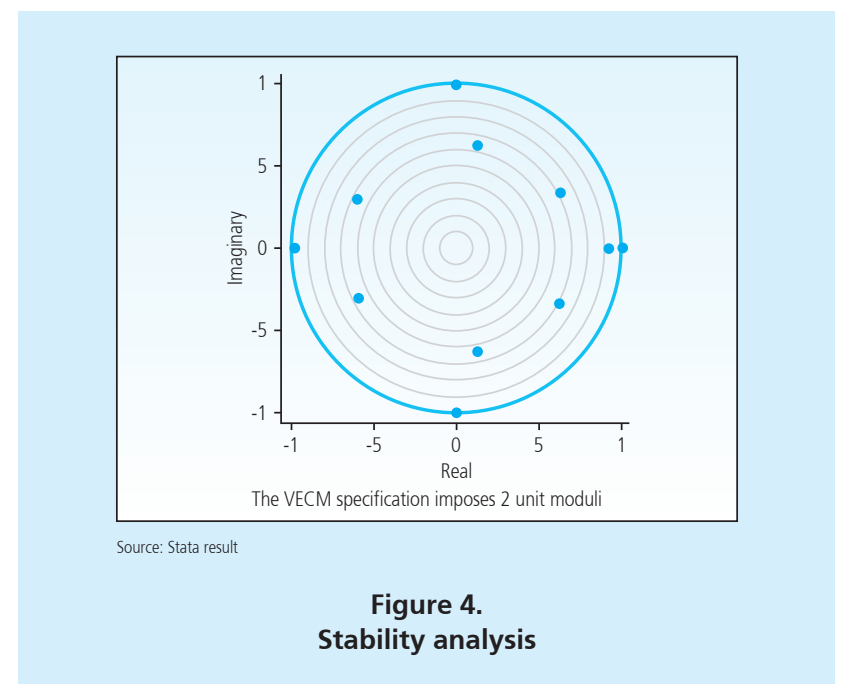

Granger (1988) has developed the causality test that expressing the ability of variable's explanation to another variable. Granger causality estimation exists if, by definition, the two variables are I(1), in turn, either feedback or one-directional relationships must hold in at least integrated order zero. Hence, according to table 5, we can draw the directed trend of Granger causality in both long run and short run and confirm the presence of whether FLGH or/and ELGH as well as GLFH or/and GLEH or both conditions exist in Indonesia. 


\begin{tabular}{|c|c|c|c|}
\hline \multicolumn{4}{|c|}{$\begin{array}{c}\text { Table } 6 . \\
\text { Multivariate granger causality estimations }\end{array}$} \\
\hline Dependent Variable & $\Delta \ln \operatorname{GDP}_{\mathrm{t}-1}$ & $\Delta$ In FDI ${ }_{t-1}$ & $\Delta \ln \mathrm{EX}_{\mathrm{t}-1}$ \\
\hline t-statistic for ECT t-1 & $-4.6^{*}$ & 0.780 & 1.010 \\
\hline$p$-value & 0.000 & 0.433 & 0.311 \\
\hline Wald statistic for $\Delta$ In GDPt-1 & - & 0.476 & $3.0803^{* *}$ \\
\hline$p$-value & - & 0.753 & 0.027 \\
\hline Wald statistic for $\Delta$ In FDIt-1 & $3.0364^{*}$ & - & $3.1945^{\text {** }}$ \\
\hline$p$-value & 0.029 & - & 0.023 \\
\hline Wald statistic for $\Delta \ln$ EXt-1 & 1.426 & $2.6644^{* *}$ & - \\
\hline$p$-value & 0.244 & 0.047 & - \\
\hline Wald statistic for ALL & $3.0884^{*}$ & 1.474 & $3.2008^{*}$ \\
\hline$p$-value & 0.009 & 0.199 & 0.007 \\
\hline \multicolumn{4}{|c|}{$\begin{array}{l}\text { Note: - The two last rows reports The Wald statistic for The significance of joint estimation } \\
\text { - P-value shows the significance level by }{ }^{*}=1 \% ;{ }^{* *}=5 \% ;{ }^{* *}=10 \% \\
\text { Source: Stata result }\end{array}$} \\
\hline
\end{tabular}

The empirical results of the Granger causality test and adjustment term are presented in table 6 . This table is constructed by the statistically critical level of coefficients which express the dynamics of short-run circumstance in the multivariate error correction model. It can be seen from the table, there is a significant causality from inward FDI to Indonesia's growth not in reversal way. Instead exports do not cause growth, in turn, FDI and exports jointly influence growth by 1 per cent of significance level. Moreover, the Granger test also shows that growth considerably causes exports. There is likewise another interesting result that FDI has causality on exports. Hence, joint variables between growth and FDI cause exports at 1 per cent critical level. It implies FDI lead directly to both Indonesia's exports and growth.

According to all results provided, several findings can be illustrated. The existence adjustment term in the FDI-export-GDP model leads to the significance of relevant effects in long run coming along with the interactive relationship between FDI and exports to GDP. It is likely to infer in the long run that the FDI-led growth and export-led growth hypothesis in Indonesia exist with the relatively identical effects on GDP. The significant intuition on the relationship of variables is also presented by the short-run investigation. By definition, Indonesia can adjust their FDI and exports performances through some effective policies to drive back output into steady state output level when it is deviated away from equilibrium phase. 


\section{CONCLUSION}

This paper presents an empirical study of the FDI-export-GDP nexus in Indonesia using data from 2000:01 to 2012:04. By operating current advanced modelling for time series framework, this paper investigates the causality relationship among FDI, exports and GDP growth in the short run and long run of time dimension. The findings show that the FDI-exports-GDP growth nexus has a positive long run relationship supported partially from the convincing performances of exports and FDI. In turn, it confirms that the FDI-led growth and export-led growth hypothesis exist in the long run.

The findings in Indonesia's case verify the proposition that FDI plays an important role which, in turn, together with joint FDI-exports can promote economic growth in the immediate short run and improve the competitiveness for Indonesia's commodity exports. This performance is also strengthened indirectly by the increasing FDI that Granger cause exports in order to boost output growth. This condition may occur due to technology spillover and the increasing production capacity. Nonetheless, the absence and existence of economic growth effects to FDI and exports respectively indicate that Indonesia still has several domestic economic constraints, such as lack of infrastructure improvement, the rigidity in labour market and resources-driven income. It denotes that Indonesia's economic structure is still transforming. At the same time, current export performance is attracting foreign investors to increase investment in Indonesia. The reason can be seen as the attractiveness of trade relations between Indonesia and other countries, in particular South-East-South East Asian regions, and the presence of abundant factor endowments which creates both lower operational and trade costs.

The results reveal important insights of policy implication that Indonesia's economic policy is still far from adequate. Indonesia needs bold policies in order to accelerate its economic growth and further integrate trade chains. In terms of policies, this study proposes a reform in economic policy which can confirm reducing domestic economic restrictions and improving Indonesia's degree of competitiveness. These reforms are desirable to ensure the change in Indonesia's economic structure is on the right path for prosperity. 


\section{REFERENSI}

Andraz, JM \& Rodrigues, PMM. (2010). What Causes Economic Growth In Portugal: Exports or inward FDI?. Journal of Economic Studies. 37 (3), 267-287.

Attari, MIJ; Kamal, Y \& Attaria, SN (2011). The Causal Link Between Foreign Direct Investment (FDI) and Economic Growth In Pakistan Economy. The Journal of Commerce. 3 (4), 61-68.

Bahmani-Oskooee, M \& Economidou, C. (2009). Export led Growth vs. Growth led Exports: LDCs Experience. The Journal of Developing Areas. 42 (2), 179-209.

Balassa, B. (1978). Exports and Economic Growth. Journal of Development Economics. 5, 181 -189 .

Chakraborty, C \& Basu, P. (2002). Foreign Direct Investment And Growth in India: a CoIntegration Approach. Applied Economics. 34 (9), 1061-1073.

Dickey, DA \& Fuller, WA. (1979). Distribution of The Estimators for Autoregressive Time Series With A Unit-Root. Journal of the American Statistical Association. 74 (366), 427-431.

Doyle, E. (2001). Export-Output Causality and The Role of Exports in Irish Growth: 1950-1997. International Economic Journal. 15 (3), 31-54.

Elliott, G; Rothenberg, TJ and Stock, JH. (1996). Efficient Tests For an Autoregressive Unit Root. Journal of Econometrica. 64 (4), 813-836.

Engle, RF \& Granger, CWJ. (1987). Co-integration and Error Correction: Representation, Estimation, and Testing. Journal of Econometrica. 55 (2), 251-276.

Felipe, J. (2003). Is Export-led Growth Passe? Implications for Developing Asia. ERD Working Paper Series. 48. Asian Development Bank.

Gagnon, JE. (2008). Growth-led Exports: Implications for The Cross-country Effects of Shocks to Potential Output. International Finance Discussion Papers. 822. The Federal Reserve. USA.

Giles, JA \& Williams, CL. (2000a). Export-led Growth: A Survey of The Empirical Literature and Some Non-Causality Results. Journal of International Trade and Economic Development. 9 (3), 261-337.

Giles, JA \& Williams, CL. (2000b). Export-led Growth: A Survey of The Empirical Literature and Some Non-Causality Results. Journal of International Trade and Economic Development. 9 (4), 445-470.

Gharana, KKG \& Adhikari, DR. (2011). Econometric Investigation of Relationships among Export, FDI and Growth in China: an application of Todayamamoto-Dolado-Lutkephol Granger Causality Test. Journal of International Business Research. 10 (2), 31-50. 
Gossel, SJ \& Biekpe, N. (2013). Economic Growth, Trade and Capital Flows: a Causal Analysis of Post-liberalised South Africa. The Journal of International Trade and Economic Development: An International and Comparative Review, (http://dx.doi.org/10.1080/09638199.2013.78 6118)

Granger, CWJ. (2010). Some Thoughts on The Development of Cointegration. Journal of Econometrics. 158, 3-6.

Granger, CWJ. (1988). Some Recent Developments in The Concept of Causality. Journal of Econometrics. 39, 199-211.

Granger, CWJ \& Newbold, P. (1974). Spurious Regressions in Econometrics. Journal of Econometrics. 2, 111-120.

Johansen, S. (1991). Estimation and Hypothesis Testing of Cointegration Vectors in Gaussian. Econometrica. 59 (6), 1551-1580.

Johansen, S. (1988). Statistical Analysis of Co-integration Vectors. Journal of Economic Dynamics and Control. 12, 231-254.

Kinda, T. (2010). Investment Climate and FCl in Developing Countries: Firm-level Evidence. World Development. 38. (4), 498-513.

Kohpaiboon, A. (2003). Foreign Trade Regimes and The FDI-Growth Nexus: A Case Study of Thailand. The Journal of Development Studies. 40 (2), 55-69.

Kondeker M \& Kalirajan, K. (2010). Determinants of Foreign Direct Investment in Low-income and Lower-middle Income Countries: A Comparative Analysis. ASARC Working Paper Series. 13. The Australian National University. Australia South Asia Research Centre, Australia.

Li, X \& Liu, X. (2005). Foreign Direct Investment and Economic Growth: An Increasingly Endogenous Relationship. World Development. 33 (3), 393-407.

Makki, SS \& Somwaru. (2004). Impact of Foreign Direct Investment and Trade on Economic Growth: Evidence from Developing Countries. American Journal of Agricultural Economics. 86 (3), 795-801

Nabende, AB; Ford, JL; Santoso, B \& Sen, S. (2003). The Interaction between FDI, Output and The Spillover Variables: Co-Integration and VAR Analyses for APEC, 1965-1999. Applied Economics Letters. 10 (3), 165-172.

Narayan, PK \& Smyth, R. (2004). Temporal Causality and The Dynamics of Exports, Human Capital and Real Income in China. International Journal of Applied Economics. 1 (1), 24-45. 
Ng, S \& Perron, P. (2001). Lag Length Selection and The Construction of Unit Root Tests with Good Size and Power. Journal of Econometrica. 69 (6), 1519-1554.

Ngoc, PM. (2008). The Roles of Capital and Technological Progress in Vietnam's Economic Growth. Journal of Economic Studies. 35 (2), 200-219.

Oladipo, OS. (2013). Does Foreign Direct Investment Cause Long Run Economic Growth? Evidence from The Latin American and the Caribbean Countries. International Economics and Economic Policy. 10 (4), 569-5 
488 Buletin Ekonomi Moneter dan Perbankan, Volume 19, Nomor 4, April 2017

This page intentionally left blank 